IIIIIIIIIIIIIIIIIIIIIIIIIIIIIII

読み物シリーズ

IIIIIIIIIIIIIIIIIIIIIIIIIIIIIIIII

\title{
各地の生産現場から $(6)^{\#}$
}

会員間の情報交換をさらに活発にするため, 実際に農薬を使用する生産現場からの情報提供を企画した. 各地の農業の特色 や新しい取り組み, マイナー作物の生産動向, 農薬の安全使用に向けた取り組み, 総合的病害虫・雑草管理や総合的作物管理 などに関する事例を都道府県の農業試験場等から紹介していただく予定である.

今回はオーガナイザーから執筆を依頼したが，オーガナイザーや編集委員会では各地の情報を十分には収集できていないの で，執筆の立候補や執筆者の推薦を，会員の皆様に是非お願いしたい。

$$
\text { 本シリーズの掲載内容 }
$$

(39巻 2 号)

高知県におけるマイナー作物の農薬登録促進

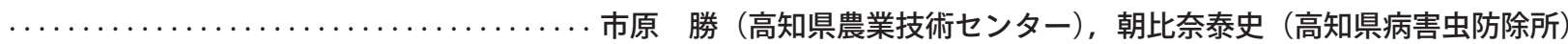

愛知県におけるマイナー作物の農薬登録適用拡大の取り組み

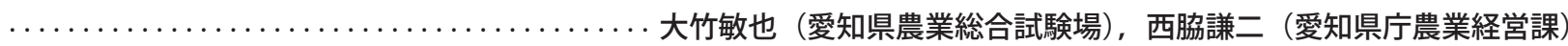

(40巻 1 号)

徳島県サツマイモ産地の環境に配慮したクロルピクリン剂使用法の推進

田中昭人，村井恒治，米本謙悟（徳島県立農林水産総合技術支援センター）

(40巻 2 号)

残留農薬自主検査の価值を高めるために……島村裕二（全国農業協同組合連合会営農・技術センター残留農薬検査室） (41巻 1 号)

JAふかやにおけるイムノアッセイ法を利用した農薬残留分析の試み

…………田中裕子（ふかや農業協同組合北部営農経済センター），成田伊都美（埼玉県農業技術研究センター）

JA あいち経済連における農薬の安全使用に向けた取り組み

永井雄太郎（JA あいち経済連営農支援センター），原 広志（JA あいち経済連営農総合室）

(41巻 2 号)

「梨病害防除ナビゲーション」システムを利用したナシ黒星病の薬剂防除およびシステムの改良 (今号)

東京都島しょ地域における特産作物の農薬登録

$\ldots \ldots \ldots \ldots \ldots \ldots \ldots \ldots \ldots \ldots \ldots \ldots \ldots \ldots \ldots$ 竹内悠里（東京都家畜保健衛生所），橋本良子（東京都農林水産振興財団）（168）

オーガナイザー：山本幸洋（常任編集委員，千葉県農林総合研究センター）

夏目雅裕（編集委員長，東京農工大学大学院農学研究院）

\footnotetext{
\# Reports from local production sites utilizing pesticides (6)

(C) 日本農薬学会
} 